International Journal of Current Advanced Research

ISSN: O: 2319-6475, ISSN: P: 2319 - 6505, Impact Factor: SJIF: 5.995

Available Online at www.journalijcar.org

Volume 6; Issue 3; March 2017; Page No. 2964-2966

DOI: http://dx.doi.org/10.24327/ijcar.2017.2966.0155

Research Article

\title{
DETECTION OF NEUC GENE ENCODING CAPSULAR POLYSACCHARIDE AMONG THE URINARY ISOLATES OF ESCHERICHIACOLI FROM TERTIARY CARE HOSPITAL IN KANCHEEPURAM DIST
}

\author{
Rinieshah Nair ${ }^{1}$ and P. Gopinath ${ }^{2 *}$ \\ ${ }^{1}$ Saveetha Dental College, Chennai \\ ${ }^{2}$ Department of Microbiology, Saveetha Dental College, Chennai
}

\section{A R T I C L E I N F O}

\section{Article History:}

Received $18^{\text {th }}$ December, 2016

Received in revised form $16^{\text {th }}$ January, 2017

Accepted $26^{\text {th }}$ February, 2017

Published online $28^{\text {th }}$ March, 2017

Key words:

Escherichia coli, capsular polysaccharides, neuC gene, PCR.

\begin{abstract}
A B S T T R A C T
Capsular polysaccharides ( $\mathrm{K}$ antigens) are one of the main virulence marker for E. coli strains to cause urinary tract infections and neonatal meningitis. There are 50 chemically different capsular $\mathrm{K}$ antigens found, in which only a few are associated with infective E.coli strains.We have taken this study to detect the gene responsible for expression of K1 polysaccharide in E. coli isolates. 3/20 (15\%) clinical isolate of urinary isolates of E.coli was found to harbour neuCgene.The pathogenicity of urinary tract infections by these pathogens might be crucially played by this gene encoding K capsular polysaccharide.
\end{abstract}

Copyright $\subseteq 2017$ Rinieshah Nair1 and P. Gopinath. This is an open access article distributed under the Creative Commons Attribution License, which permits unrestricted use, distribution, and reproduction in any medium, provided the original work is properly cited.

\section{INTRODUCTION}

Escherichia coli is a normal inhabitant of the gut micro flora. Some of the strains of E. coli cause severe human infections and many isolates of E. coli are found to produce extracellular polysaccharide capsules ${ }^{[1]}$. Capsular polysaccharides (K antigens) are one of the main virulence marker for E. coli strains to cause urinary tract infections and neonatal meningitis ${ }^{[2] .}$ There are 50 chemically different capsular $\mathrm{K}$ antigens found, in which only a few are associated with infective E.coli strains. These polysaccharides associated with infections that are encoding with K1 antigen (polysialic acid) are involved in causing a wide variety ofinfections such as septicemia, urinary tract infections, and meningitis ${ }^{[3]}$.The K1 antigen is one of the specific types of surface polysaccharidesfound among E. coli strains. There has been a vast difference in structural variability among E. coli capsules and at least 80 different $\mathrm{K}$ antigens were recognized so far. Only a few of these capsular structures have been implicated in pathogenesis of E. coli infections ${ }^{[1]}$. The pathogenicity of E. coli strains is directly correlated with the presence of numerous virulence factors ${ }^{[4]}$. The virulence of E. coli $\mathrm{K} 1+$ is related to the ability of the $\mathrm{K} 1$ capsule to inhibit phagocytosis and to resist antibody-independent serum bactericidal activity

*Corresponding author: P. Gopinath

Department of Microbiology, Saveetha Dental College, Chennai and the ability of $\mathrm{K} 1+$ strains to cross the blood-brain barrier (BBB) .Capsules protect bacteria against the host immune response. The $\alpha$-2, 8-linked neuAc polysaccharides of E.coli $\mathrm{Kl}$ and Neisseriameningitidis group $\mathrm{B}$ resemble host glycoconjugates such as cell adhesion protein $\mathrm{N}-\mathrm{CAM}^{[5]}$. The proteins necessary for synthesis, activation, and polymerization of neuAc are encoded by the 17-kbkps gene cluster of E.coli $\mathrm{K} 1^{[6]}$. Silver et al have demonstrated that cells harboring mutations in neuC become sensitive to capsular polysaccharide specific phage only when supplied with exogenous sialicacid, suggesting involvement of the neuC gene product in neuAc biosynthesis ${ }^{[7]}$ With this background, we have taken this study to detect the gene responsible for expression of $\mathrm{K} 1$ polysaccharide in $\mathrm{E}$. coli isolates.

\section{MATERIALS AND METHODS}

\section{Bacterial isolates}

A total of 20 non repetitive urinary isolates of Escherichia coli were collected from Saveetha Medical College and Hospitals, Chennai. They were processed for a battery of standard biochemical tests and confirmed. Isolates were preserved in semisolid trypticase soy broth stock and were stored at $4{ }^{\circ} \mathrm{C}$ until further use.

\section{Antibiotic susceptibility testing}

Antibiotic susceptibility test was determined for these isolates to routinely used antibiotics such as ampicillin, amoxicillin, amikacin, norfloxacin, ceftazimide, cefotaxime, ciprofloxacin 
and gentamicin, imipenem as by Kirby Bauer disc diffusion method ${ }^{[8]}$.

\section{Detection of neuCgene in E.coli}

Escherichiacoli isolates were detected for the presence of neuCgene by PCR analysis. Detection of the gene was carried out using primer as depicted in table 1. Bacterial DNA was extracted by boiling lysis method. $1 \mu \mathrm{L}$ of DNA extract was used as template for PCR reaction. The reaction mixture contained $1 \mathrm{mM}$ of $\mathrm{Mgcl}_{2} 0.2 \mathrm{mM}$ dNTP mix and $0.8 \mu \mathrm{M}$ of neuC gene with $0.5 \mathrm{U}$ of Taq polymerase (New England Biolabs) in a 1x PCR buffered reaction. A positive control of E.coli with neuCgene was also included in this study. PCR amplification was carried out using thermal cycler (Eppendorf) with the following cycling condition. Initial denaturation at $96^{\circ} \mathrm{C}$ for $5 \mathrm{~min}$ and 30 cycles for $30 \mathrm{~s}, 68^{\circ} \mathrm{C}$ for $30 \mathrm{~s}$ and $68^{\circ} \mathrm{C}$ for $60 \mathrm{~s}$, followed by a final extension of $5 \mathrm{~min}$ at $74^{\circ} \mathrm{C}$. PCR products were resolved in $1.5 \%$ agarose gel. A $100 \mathrm{bp}$ ladder was including in all the gel analysis ${ }^{[10]}$.

Table 1 Gene sequencing of neuC gene

\begin{tabular}{ccc}
\hline Primer & Primer sequence & Product size \\
\hline neuC & $\begin{array}{c}\text { AGGTGAAAAGCCTGGTAGTGTG } \\
\text { GGTGGTACATCCCGGGATGTC }\end{array}$ & $676 \mathrm{bp}$ \\
\hline
\end{tabular}

\section{RESULTS}

\section{Sample wise distribution of clinical isolates of E.coli}

Of the 20 clinical isolates of E.coli, 12/20 (60\%) were from acute urinary tract infections and $8 / 20$ (40\%) were from chronic urinary tract infections. Figure 1 depicts the sample wise distribution of clinical isolates of E.coli.

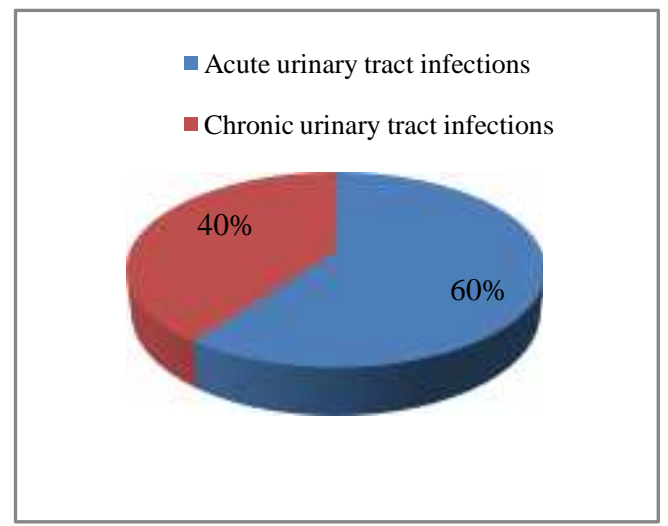

Figure 1 Sample wise distribution of urinary isolates of E.coli

\section{Antibiotic susceptibility testing}

In our isolates, we have found increased percentage 14/20 (70\%) of isolates showed sensitivity to amikacin followed by gentamicin, which showed sensitivity of 9/20 (45\%). 80- 90\% of E.coli isolates showed resistance to cephalosporin group of drugs. $6 / 20(30 \%)$ were found to be resistant to imipenem. However, we have observed an elevated level of resistance to other routinely used antibiotics. The detailed resistant pattern of E.coli isolates is shown in table 2.
Table 2 Showing antibiotic sensitivity pattern of E.coli

\begin{tabular}{cccc}
\hline Antibiotics & $\begin{array}{c}\text { Sensitivity(20) } \\
(\boldsymbol{\%})\end{array}$ & $\begin{array}{c}\text { Intermediate (20) } \\
(\boldsymbol{\%})\end{array}$ & $\begin{array}{c}\text { Resistant(20) } \\
(\mathbf{\%})\end{array}$ \\
\hline Ampicillin & 5 & 0 & 95 \\
Amoxicillin & 5 & 0 & 95 \\
Ceftazidime & 10 & 10 & 80 \\
Cefotaxime & 5 & 5 & 90 \\
Amikacin & 70 & 10 & 20 \\
Gentamicin & 45 & 20 & 35 \\
Norfloxacin & 15 & 15 & 70 \\
Ciprofloxacin & 20 & 5 & 75 \\
Imipenem & 70 & 0 & 30 \\
\hline
\end{tabular}

\section{Result ofneuCgene in E.coli}

$3 / 20(15 \%)$ clinical isolate of urinary isolates of E.coli was found to harbour neuCgene.

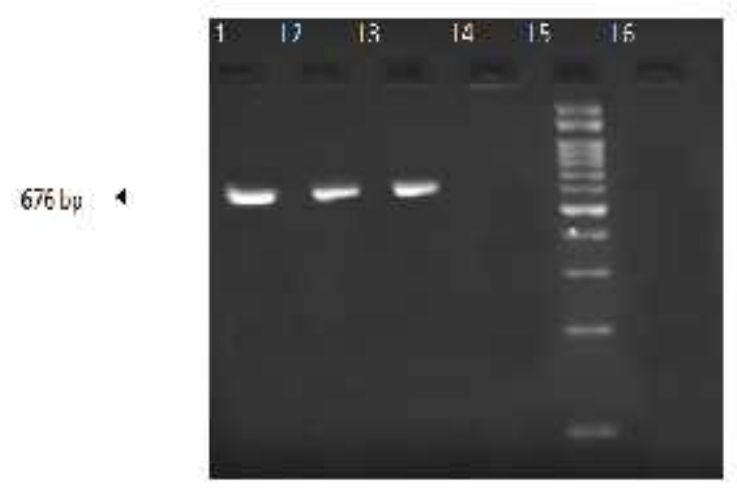

Figure 2 Representative gel picture showing positive for neuC gene

\section{DISCUSSION}

In our study we have seen $15 \%$ of our E. coli isolates from patients affected with urinary tract infections showed positive for neuC gene. This gene codes for capsular polysaccharide $\mathrm{K}$ antigen. This $\mathrm{K}$ antigen is found to regulate several functions in our system, among which resistance to phagocytosis is one of the main virulence function exhibited by this trait. Van Dijk et al showed that many of E. coli strains isolated from blood cultures positive patients with E. coli bacteremia possessed $\mathrm{K}$ antigen and were poorly phagocytized ${ }^{[9]}$. This inhibition of phagocytosis seems to be related to an impaired recognition of the $\mathrm{K}+$ strains by the phagocytes due to ineffective opsonization then resistance to intracellular killing. In contrast, we have used only isolates from acute and chronic UTI. This might play a role in showing different results by this gene than isolates from blood samples. Similarly, study of study done by Kaczmarek et al in 2012 using capsular and non capsular strains of E. coli, they have reported $37.3 \%$ of positivity. But in our study we found great positiveness in showing this gene amplicons ${ }^{[10]}$.

\section{CONCLUSION}

From our study, it is very clear that capsular polysaccharide is one of the main components in resisting the host immune response. The pathogenicity of urinary tract infections by these pathogens might be crucially played by this gene encoding $\mathrm{K}$ capsular polysaccharide. This is a basic and preliminary study. To rule out the relationship between presence of $\mathrm{K}$ capsular polysaccharide and urinary tract infections by $\mathrm{E}$. coli, more number of samples and patients from different regions having UTI have to to be included. 


\section{References}

1. Whitfield C and IS Roberts. Structure, assembly, and regulation of expression of capsules in E. coli. Mol. Microbiol. 31;1999:1307-1319.

2. KaiJser B, Hanson LA, Jodal V, Lindin-Janson G and Robbins JB. FrequencyofE.coliKantigensinurinarytractinfectionsinchildren. Lanceti.1977:664-666.

3. SilverRP and VimrER. Polysialic acid capsule of E. coli K1 in the bacteria. Molecular basis of bacterial pathogenesis. Academic Press, Inc., New York, N.Y.11;1990:39-60.

4. Watt S, Lanotte P, Mereghetti, L, Moulin-Schouleur M, Picard B \& Quentin R. Escherichia coli strains from pregnant women and neonates: intraspecies genetic distribution and prevalence of virulence factors. J Clin Microbiol 41;2003:1929-1935

5. Hoffman S, Sorkin BC, White PC, Brackenbury R, Mailhammer R, Rutishauser U, Cunningham BA and Edelman GM.Chemical characterization of a neural cell adhesion molecule purified from embryonic brain membrane. J Biol Chem 257; 1982:7720-7729.
6. Echarti CB, Hirschel GJ, Boulnois JM, Varly F, Waldvogel, and Timmis KN. Cloning and analysis of the $\mathrm{K} 1$ capsulebiosyn the sisgenes of Escherichiacoli: lack of sequences for homology with Neisseriameningitidis group BDNA sequences. Infect Immun 41; 1983:54-60.

7. Silver RP, Vann WF andAaronson W. Genetic and molecular analyses of Escherichiacoli K1 antigengenes. J Bacteriol 157; 1984:568-575.

8. Clinical and Laboratory Standards Institute. Performance Standards for Antimicrobial Disk Tests; Approved Standards; Doucement M2-A9, $9^{\text {th }}$ ed., Vol 26. Wayne, PA: CLSI; 2015

9. Van Dijk WC, Verbrugh HA, Peters R, van derTol $\mathrm{ME}$ et al. Escherichia coli $\mathrm{K}$ antigen in relation to serum induced lysis and phagocytosis. J Med Microbiol 12; 1979:123-130.

10. Kaczmarek A, Budzynska A, Gospodarek E. Prevalence of genes encoding virulence factors among Escherichia coli with $\mathrm{K} 1$ antigen and non-K1 E. coli strains. Journal of Medical Microbiology 61; 2012:1360-1365.

\section{Please cite this article in press as:}

Rinieshah Nair and P. Gopinath (2017), 'Detection of neuc gene encoding capsular polysaccharide among the urinary isolates of escherichiacoli from tertiary care hospital in kancheepuram dist', International Journal of Current Advanced Research, 6(3), pp. 2964-2966. http://dx.doi.org/10.24327/ijcar.2017. 2966.0155 